\title{
Taxonomic notes on South American Miconia (Melastomataceae). II
}

\author{
Notas taxonômicas sobre Miconia (Melastomataceae) sul-americanas. II
}

\author{
Renato Goldenberg ${ }^{1}$, Mayara Krasinski Caddah $^{2}$ \& Claire V. Martin ${ }^{3}$
}

\begin{abstract}
We propose nine new synonyms, and five lectotypifications for South American Miconia (Melastomataceae). Miconia paulensis is synonymized under $M$. cinerascens var. cinerascens; M.conferta as a synonym of $M$. inconspicua; Miconia riedelii and M. langsdorffii as a synonym of M. paucidens; M. camposnovaesii and $M$. coralliocarpa as a synonym of M. pseudonervosa; and M. hispida, M. regnellii and M. brevipes var. longifolia under M. trianae. We propose lectotypes for M. conferta, M. hispida, M. langsdorffii, M. pseudonervosa, and M. trianae.
\end{abstract}

Key words: lectotypes, South America, synonymy, taxonomy.

\section{Resumo}

São apresentados nove novos sinônimos e cinco lectotipificações para Miconia sul-americanas. Miconia paulensis é sinonimizada sob $M$. cinerascens var. cinerascens; $M$. conferta sob M. inconspicua; M. riedelii e M. langsdorffii sob M. paucidens; Miconia camposnovaesii e M. coralliocarpa sob M. pseudonervosa e $M$. hispida, M. regnellii e M. brevipes var. longifolia sob M. trianae. São escolhidos lectótipos para M. conferta, M. hispida, M. langsdorffii, M. pseudonervosa e M. trianae.

Palavras-chave: América do Sul, lectótipos, sinonímias, taxonomia.

\section{Introduction}

Miconia Ruiz \& Pav. has about 1000 species occurring through tropical and subtropical America (Goldenberg et al. 2008). The last complete revision of the genus is more than 100 years old (Cogniaux 1891), although parts of it have been recently revised, such as section Hypoxanthus (Rich. ex DC.) Hook.f. (Goldenberg 2000) and the Antillean species of section Chaenopleura (Rich. ex DC.) Hook.f. (Judd 2007). Several nomenclatural and taxonomic arrangements have been published in regional floras (Wurdack 1962, 1973, 1980; Wurdack et al. 1993), and recent papers (Goldenberg \& Martin 2008) but much work on this group's taxonomy remains to be done. In this paper, we address problems related to names and species found during work on the taxonomy of Brazilian Miconia, and during the preparation of the database for the project List of Species of the Brazilian Flora (Forzza 2009).

\section{Materials and Methods}

The synonymizations and lectotypifications that are presented here were based on the analyses of specimens from the herbaria BM, BR, C, ESA, F, FI, G, GUA, HB, K, L, M, MBM, MO, NY, P, R, RB, $\mathrm{S}$, SP, UPCB, US, and W (acronyms following Holmgren et al. 1990).

\section{Results and Discussion}

1. Miconia cinerascens Miq. var. cinerascens, Linnaea 22: 543. 1849. Type: BRAZIL. MINAS GERAIS: cidade de Caldas, 1847, A.F. Regnell II.109* (isotype S, image at UPCB!).

Miconia paulensis Naudin, Ann. Sci. Nat. Bot., ser. 3, 16: 187. 1850. Type: BRAZIL. Province de San Paolo, 1833, C. Gaudichaud 777(holotype P!), syn nov.

It occurs in Paraguay, Argentina and Brazil, in the states of Mato Grosso do Sul, Minas Gerais, Rio de Janeiro, São Paulo (Martins et al. 1996),

\footnotetext{
'Universidade Federal do Paraná, Depto. Botânica, Campus do Centro Politécnico 81540-560, Curitiba, Paraná, Brazil. rgolden@ufpr.br. Author for correspondence. ${ }^{2}$ Universidade Estadual de Campinas, Depto. Biologia Vegetal, Programa de Pós-Graduação em Biologia Vegetal.

${ }^{3}$ Bambouseraie de Prafrance, Générargues, France.
} 
Paraná (Goldenberg 2004), Santa Catarina (Wurdack 1962) and Rio Grande do Sul.

Additional specimens: BRAZIL. W.J. Burchell 963, 1396 (K); F. Sello s.n. (K, P, US); F. Sello 391 (US); 19.II.1862 or 16.XII.1873, A.F. Regnell II.109* (P). MATO GROSSO DO SUL: Iguatemi, 21.X.1987, G.G. Hatschbach 51504 (MBM, UPCB). MINAS GERAIS: G.H. Langsdorff s.n. (K, P); 1845, J.F. Widgren 1144 (US); 10.VI.1861, A.F. Regnell II.109(US); 1.XI.1864, A.F. Regnell II.109 (P). Passa Quatro, 4.IV.1995, R. Goldenberg 130 (UEC, UPCB). Poços de Caldas, 19.XII.1963, M. Emmerich 1601 (US). RIO DE JANEIRO: 1832, L. Riedel 1189 (K, P); 1832, L. Riedel 1417 (K, P); 1841, G. Gardner 5451 (K); I.1850, P. Clausen 253 (P); Alto Macaé, 8.XII.1888, A. Glaziou $17562 a$ (P). SÃO PAULO: P. Lund s.n. (P); XII.1833, L. Riedel 1762 (K, P); Butantan, 17.III.1919, F.C. Hoehne 3079 (NY, US). Campos do Jordão, 16.V.2004, F. Arzolla 553 (UPCB). PARANÁ: Tibagi, 27.X.2005, $R$. Goldenberg 822 (NY, UPCB). União da Vitória, 18.XI.1972, G.G. Hatschbach 30671 (MBM, US). SANTA CATARINA: Lages, IV.1963, R. Reitz 14887 (MBM). Tangará, X.2005, G. Amaral 27-AX (MBM). RIO GRANDE DO SUL: São Francisco de Paula, V.1995, R. Wasum s.n. (MBM 21667); II.2000, Wasum 471 (MBM). ARGENTINA. MISIONES: Guarani, 26.XI.1993, S.G. Tressens 4681 (MBM). São Pedro, XI.2000, M. Romero 2636 (MBM). PARAGUAY. CAAZAPA: Yuty, 10.IX.1987, E.M. Zardini 2937 (US). CANENDIYU: 16.II.1984, W. Hahn 2135 (US).

According to Cogniaux (1886-1888), Miconia paulensis should have lanceolate, 3-nerved leaves, with entire or undulate-subdenticulate margins, while $M$. cinerascens should have oblong to ovaloblong, 5-nerved leaves, with crenulate-denticulate margins. There are several specimens with narrower leaves that fit the description of $M$. paulensis, although none with entire margins. The number of nerves is also not reliable, since most specimens have 3 main nerves plus an additional, faint and submarginal pair, which was the one that Cogniaux probably considered as the $4^{\text {th }}$ and $5^{\text {th }}$ nerves, and which can almost always be seen even in the narrower leaves, although very thin. Moreover, the types of both $M$. cinerascens and $M$. paulensis are strikingly alike and do not fit Cogniaux's distinction between the two species: Gaudichaud 777 (M. paulensis) has clearly dentate margins, and at least one of the leaves has a clear second pair of nerves, while Regnell II.109* (M. cinerascens) has 3nerved, lanceolate leaves. As suggested before by Wurdack (1962) and Goldenberg (2004), M. paulensis is a synonym, since it falls within the variation found for the broadly distributed and variable $M$. cinerascens.
There are specimens collected by Regnell in $\mathrm{P}$, numbered as II.109* (the same as the type), but dated from 1862 and 1873. These collections were not listed as isotypes, since they were subsequent to the publication of M. cinerascens (Miquel 1849).

2. Miconia inconspicua Miq., Linnaea 22: 542. 1849. Type: BRAZIL. 1847,A.F. Regnell II.110(isotype S, image at UPCB!).

Miconia conferta Cogn. in Mart., Eichler \& Urban, Fl. bras. 14(4): 416. 1888. Type: BRAZIL. RIO DE JANEIRO: Resende, Faz. Taquaral, 25.IX.1874, A. Glaziou 7627 (lectotype P!, designated here; isolectotypes $\mathrm{C}, \mathrm{K}$ !, LE, P!-2 sheets, R!), syn nov.

It occurs only in Brazil, in the states of Minas Gerais, Rio de Janeiro, São Paulo (Martins et al. 1996), Paraná (Goldenberg 2004), and Santa Catarina (Wurdack 1962).

Additional specimens: BRAZIL. F. Sello 1019 (US); 1837, Herb. Mus. Vindob. 1168 (K). MINAS GERAIS: C.J.F. Bunbury s.n. (syntype of M. conferta, BR). Araponga, 2004, M.P. Soares s.n. (UPCB). Itabira, 5.VII.2002, A.M. Oliveira 103 (UPCB). Poços de Caldas, 9.IX.1864, A.F. Regnell II.110 (P, S, US). RIO DE JANEIRO: IX.1827, L. Riedel 585 (K); 10.X.1863, A. Glaziou 17556 (G, K, P, US). SÃO PAULO: IX.1824, L. Riedel 565 (P); 22.IX.1931, F.C. Hoehne s.n. (K). Cruzeiro, 5.IV.1995, R. Goldenberg 62 (UEC). PARANÁ: Cerro Azul, 3.X.1973, G.G. Hatschbach 32626 (MBM, US). Prudentópolis, 11.IV.2003, R. Goldenberg 596 (UPCB). SANTA CATARINA:Campo Alegre, 18.X.1957, R. Reitz 5213 (NY, US).

Cogniaux (1886-1888) distinguished Miconia inconspicua from $M$. conferta by its pedicellate, non glomerulate flowers with obverse-oblong anthers and exerted style, whereas the later would have sessile, glomerulate flowers with broadlytriangular to subglobose anthers and included style. The differences regarding the inflorescences actually do not exist: both syntypes of $M$. conferta do not have glomerulate flowers, even if one of them (Glaziou 7627) looks glomerulate because the inflorescences are rich and bear too many opened flowers that conceal the inflorescence axes. As for the other characters, the shorter stamens and style from what Cogniaux called $M$. conferta fall within the variation found for M. inconspicua, which can be confirmed now that many more samples are available for study than were at the end of the $19^{\text {th }}$ century. Moreover, there are specimens with both exerted and included styles in different flowers ( Glaziou 17556, K), flowers with longer anthers and short styles (Hoehne s.n., K), 
and styles with an intermediate size, i.e. neither included nor exerted, right at the same level of the stamens apices (Hatschbach 32636, US).

There are some specimens collected by Regnell in S, numbered as II.110 (the same as the type), but dated from 1864 and 1866 . These collections were not listed as isotypes, since they were subsequent to the publication of $M$. inconspicua (Miquel 1849). There is one possible isotype in $\mathrm{P}$ that also mentions the year 1864, but this date has been marked and commented as "etiquette erronné".

3. Miconia paucidens DC., Prodr. 3: 186. 1828. Type: BRAZIL. PARÁ(?): C.F.P. Martius s.n. (holotype $\mathrm{M}$ !; isotype G-DC!).

Miconia riedelii Naudin, Ann. Sci. Nat. Bot., ser. 3, 16: 125. 1850. Type:BRAZIL. MINAS GERAIS: II.1839, L. Riedel 4 (lectotype P! designated by Martin et al. (2007); isolectotypes BR!, G!), syn nov.

Miconia langsdorffii Cogn. in Mart., Eichler \& Urban, Fl. bras. 14(4): 232. 1887. Type: BRAZIL. SÃO PAULO: G.A. Lindberg 647 (lectoype BR!, designated here; isolectotype S), syn nov.

It occurs in Paraguay and Brazil, in the states of Mato Grosso do Sul, Minas Gerais, São Paulo (Martins et al. 1996) and Paraná (Goldenberg 2004).

Additional specimens: BRAZIL. MATO GROSSO DO SUL: Amambaí, XII.1983,G.G. Hatschbach 47215 (MBM, US). Tacuru, II.1993, G.G. Hatschbach 58671 (MBM, UPCB). MINAS GERAIS: 1834-1838, F.C. Raben 424 (syntype of Miconia langsdorffii, BR-3 sheets, C); 1834-1838, F.C. Raben s.n. (syntype of $M$. langsdorffii, C). Caldas, 28.X.1846 and 28.XII.1859, A.F. Regnell I.144 (syntype of M. langsdorffii, BR, P2 sheets, S, US); A.F. Regnell III.1661 (syntype of M. langsdorffii, S, US). Jacuí, I.1994, V.C. Souza 5044 (ESA). Rio Paraíba: 1841, P. Claussen 30 (syntype of M. riedelii, P). PARANÁ: Joaquim Távora, XI.1976, G.G. Hatschbach 39284 (MBM). SÃO PAULO: $L$. Riedel 1943 (syntype of M. langsdorffii, W). Campinas, L. Riedel 69 (syntype of M. langsdorffii, B destroyed, K). Itirapina, 8.X.1992, R. Goldenberg 28492 (UEC). Mogi, C.W.H. Mosen 1032 (syntype of M. langsdorffii, S). Sorocaba, II.1834, P. Lund 2285 (syntype of $M$. langsdorffii, C). Near Sabará, L. Riedel 1604 (syntype of M. langsdorffii, K, LE, P-2 sheets, W). PARAGUAY. ALTO PARANÁ: Itaquyry, X.1995, A. Schinini 29971 (US). AMAMBAY: 1907/1908, E. Hassler 10824 (LIL). CAAGUAZU: B. Balansa 1931 (G).

The synonymization of Miconia langsdorffii under M. paucidens has been suggested by J.J. Wurdack (mss. in the picture of the type in US). Cogniaux (1886-1888) described M. langsdorffii based on its leaves with basal nerves, different from M. paucidens that, according to him, should have suprabasal nerves. The position of the main nerves in the whole species varies from basal to very shortly (up to $2 \mathrm{~mm}$ ) suprabasal, sometimes varying even within different leaves from the same plant, as this is actually the case of the type. Moreover, one of the syntypes of M. langsdorffii (Regnell III.1661, US) has leaves with clearly suprabasal nerves. The following syntypes of $M$. langsdorffii have not been seen for this study: F. Sellow s.n. (B, destroyed), G.H. Langsdorff 201 (B destroyed, LE) and G.H. Langsdorff 1311 (LE).

Miconia riedelii had also been distinguished from M. paucidens by Cogniaux (1886-1888) based on the position of the nerves in the leaves. The distinction between $M$. riedelii and $M$. langsdorffii, following the same author, was based on the serrate margin and slightly puberulous abaxial surface of the leaves and the short external calyx lobes in the former. On the other hand, M. langsdorffii should have glabrescent leaves, that should be serrate only along its upper half, and slender, subulate external calyx lobes. As for the leaf margins and pubescence, the differences are not consistent. Regarding the external calyx lobes, from the two syntypes of $M$. riedelii, Riedel 4 surely has the lobes shorter than usual, though distinct, while Claussen 30 has some flowers with short lobes and some buds with subulate lobes; Riedel 1604 (syntype of M. langsdorffii) has calyx lobes with intermediate size. This single character is apparently not enough to keep these species as different entities.

The type of $M$. paucidens does not have reproductive parts, therefore is not useful for the discussion about the calyx lobes. Its locality (Pará) is probably wrong, as also suggested by J.J. Wurdack (mss. in the picture of the type in US), since these plants have not been recently collected north of Minas Gerais or Mato Grosso do Sul. The collection Balansa 1931, from Paraguay, was wrongly cited by Cogniaux (1891) as Miconia elaeodendron (DC.) Naudin.

4. Miconia pseudonervosa Cogn. in Mart., Eichler \& Urban, Fl. bras. 14(4): 337. 1887. Type: BRAZIL. MINAS GERAIS: near Engenho do Mello Franco, J.B.E. Pohl 2889 (lectotype BR!, designated here; isolectotypes BR!, LE, NY!, W).

Miconia coralliocarpa S.Moore, Trans. Linn. Soc. London, ser. 2, 4: 363. 1895. Type: BRAZIL. MATO GROSSO: Serra da Chapada, S. Moore 173 (holotype BM!; isotype BM!), syn nov. 
Miconia camposnovaesii Hoehne, Anexos Mem. Inst. Butantan, Sec. Bot. 1(5): 136. 1922. Type: BRAZIL. SÃO PAULO: Valinhos, J. Campos Novaes s.n. (holotype SP 7469!), syn nov.

It occurs only in Brazil, in Mato Grosso, Mato Grosso do Sul, Goiás, Distrito Federal, Minas Gerais, São Paulo (Martins et al. 1996), and Rio de Janeiro. Additional specimens: BRAZIL. DISTRITO FEDERAL: 24.VIII.1981, J.F. Kirkbride 4347(MBM, NY). MATO GROSSO: No precise locality, "Expedition Base Camp", 16.IX.1968, R.M. Harley 10059 (NY); "Reserva do Cabaçal", 9.V.1995, G.G. Hatschbach 62557 (MBM). MATO GROSSO DO SUL: Rio Verde de Mato Grosso, 28.VIII.1973, G.G. Hatschbach 32455 (MBM). Sonora, 17.VIII.2002, V. Pott 5670 (UPCB). GOIÁS: No precise locality, "Aldea Caretas do Pedro Terceiro", J.B.E. Pohl 1178 (K);J.B.E. Pohl 1705 (syntype of M. pseudonervosa, NY). Luziânia, 5.IX.1978, E.P. Heringer 17332 (NY). Pirenópolis, 9.VI.1995, F.C.A. Oliveira 388 (UEC). MINAS GERAIS: Delfinópolis, 23.V.1996, J.A. Nakajima 1765 (F). No precise locality, "Engenho do Mello Franco", J.B.E. Pohl 1197 (syntype of Miconia pseudonervosa, BR, K, NY); J.B.E. Pohl s.n. (BM). SÃO PAULO: Cajuru, III.1857, A.F. Regnell III.23 (syntype of M. pseudonervosa, BR-fragm., P, S). Campinas, A.E. Severin 160 (syntype of $M$. pseudonervosa, S). Itirapina, XI.1992, R. Goldenberg 43 (UEC). Franca, VI.1834, L. Riedel 2700 (syntype of M. pseudonervosa, P-2 sheets).

While describing Miconia camposnovaesii, Hoehne (1922) distinguished it from M. nervosa $(\mathrm{Sm}$.) Triana and M. ceramicarpa var. candolleana Cogn. by its leaf pubescence "cinereous-whitish below, with soft and slightly appressed trichomes that are more dense on the nerves". The author also mentioned differences in the shape and size of the leaves, although not explaining these differences. Curiously enough, he did not mention differences between his new species and M. pseudonervosa, despite the fact that he listed some specimens of the later in the following page after the description of M. camposnovaesii. The type specimen, Campos Novaes s.n., agrees with Cogniaux's (1886-1888) description of M. pseudonervosa on having distinct petioles and blades with acute to obtuse base and short acuminate apex, rather than subsessile or short-petiolate leaves with decurrent base and long-acuminate apex of $M$. nervosa. The type of M. camposnovaesii surely has smaller leaves and inflorescences, as well as denser and longer trichomes than is the usual in M. pseudonervosa. These characters can be frequently found among the rather rich sampling of this species in São Paulo, usually in specimens collected in drier and less shaded places. The distinction between $M$. pseudonervosa and $M$. nervosa is not clear, and deserves further study in order to verify their distinction.

If one looks at the entire variation and geographical range of Miconia pseudonervosa, $M$. coralliocarpa would sit at the opposite side where $M$. camposnovaesii should be. Its type has been collected in Mato Grosso, the northern limit of M. pseudonervosa, and it has broader leaves, with rather sparse indument both on the leaves and hypanthia. The distinction between $M$. pseudonervosa and $M$. coralliocarpa, as proposed by Moore (1895), lies mostly on the size of flower parts: the petals, stamens and style would be larger in the latter. The author also mentioned red petals for $M$. pseudonervosa, which is not true, since they range from light pink to white, as is the case of the type of $M$. coralliocarpa. Moore (1895) also cited the inflorescences with more flowers in M.pseudonervosa, which is true for Pohl s.n. (BM, probably a syntype, and the plant based on which he probably drew the comparisions between the two species), but which is not the case of several collections of this species (i.e. Campos Novaes s.n., the type of M. camposnovaesii). The diagnostic characters of $M$. coralliocarpa are not consistent with the variation found in $M$. pseudonervosa, since the sampling is much richer today.

One syntype of Miconia pseudonervosa ( $L$. Riedel 1907, LE) have not been seen for this study, as well as the original collections from Pohl at W. The duplicates at NY, K, and P have often more than one number in each sheet, which makes some confusion when listing the syntypes.

5. Miconia trianae Cogn. in Mart., Eichler \& Urban, Fl. bras. 14(4): 394. 1888, “M. trianaei". Type: BRASIL. MINAS GERAIS: C.F.P. Martius 943 (lectotype BR!, designated here; isolectotypes BM!, FI!, G!, K!, L!, LE, M!, MO!, P!-2 sheets).

Miconia hispida Cogn. in Mart., Eichler \& Urban, Fl. bras. 14(4): 395. 1888. Type: BRAZIL. MINAS GERAIS: J.F. Widgren 510 (lectotype S!, designated here), syn. nov..

Miconia regnellii Cogn. in Mart., Eichler \& Urban, Fl. bras. 14(4): 396. 1888. Type: BRASIL. MINAS GERAIS: Campo ad fluvium Sapucahy ad Baguary (cited as "Caldas" by the author), 5.V.1869, S.E. Henschen s.n. (holotype S!; isotypes F!, US!; cited as Regnell III.544a by the author), syn. nov.

Miconia brevipes var. longifolia Cogn. in Mart., Eichler \& Urban, Fl. bras. 14(4): 345. 1888. Type: BRASIL. MINAS GERAIS: Lagoa Santa, 17.X.1964, E. Warming 2189 (holotype C!; isotype P!), syn. nov. It occurs only in Brazil, in Bahia (doubtfully), Espírito Santo, Minas Gerais, and São Paulo. 
Additional specimens : BRAZIL. BAHIA: Ilhéus, 1888, A. Glaziou 16931 (BR-2 sheets, C, K, P-3 sheets, R). ESPÍRITO SANTO: Cachoeiro do Itapemirim, 2.IX.1948, A.C. Brade 19124 (RB, US). MINAS GERAIS: 1844, H.A. Weddell 1064 (P);P. Clausen s.n. (G, K, P);L. Riedel 1411 (syntype of Miconia hispida, BR, fragm., K); $L$. Riedel s.n. (BR); C.A.W. Schwacke s.n. (BR). Alfenas, 30.V.1982, M.C. Weyland 558 (GUA, UEC). Belo Horizonte, 6.VI.1934, M. Barreto 6715 (SP). Caratinga, 24.XI.1983, K. Strier 649 (NY, US). Conceição do Mato Dentro, Rio Vermelho, 10.V.1986, M.S. Menandro 72 (UEC, US). Itabira, 11.IX.1887, C.A.W. Schwacke s.n. (R 167734). Juiz de Fora, 26.VIII.2002, D.S. Pífano 404 (UPCB). Mariana, 2.II.1971, H.S. Irwin 29650 (C, F, K, NY, US). Ouro Preto (Villa Rica), 1833, A.C. Vauthier 39 (P). Serro, Pedro Lessa, 13.III.1982, G.G. Hatschbach 44704 (BR, C, MBM, NY, US). No precise locality, VIII.1839, P. Clausen 197 (syntype of M. trianae BR, P4 sheets); 1816-1821, A. Saint Hilaire B1-916 (P); 18161821, A. Saint Hilaire B1-972 (P). SÃO PAULO: Jaú, 25.IV.1956, O. Handro 633 (HB, SP, SPF, US). Jundiaí, VII.1995, R. Goldenberg 40 (UEC). Rio Claro, 7.VI.1988, A. Löfgren or Com. Geol. Geog. S. Paulo 606 (BR, C, P, SP). NO PRECISE LOCALITY: IX.1821, L. Riedel 1705 (syntype of M. hispida, K, P); Herb. Mus. Vindob. (Pohl or Sello) $1256(\mathrm{~K})$.

The three species described by Cogniaux Miconia trianae, $M$. regnelii and $M$. hispida were distinguished by the unbranched hairs on the adaxial surface of the leaves of M. hispida and $M$. regnelii, that should be absent in $M$. trianae, and by the long bracteoles and filiform style (this not thickened at apex) in $M$. regnellii, these last characters absent in the others. Cogniaux (18861888) also mentioned differences in the leaf margins and surface of the ovary apex. The adaxial surfaces of the leaves of the plants named by Cogniaux (1886-1888) as M. hispida certainly have denser indument, but the trichomes also occur, even in small quantities, on the leaves of the specimens recognized by him as $M$. trianae. This is the case of Martius 943 (lectotype), which has scattered trichomes and Glaziou 16931 (cited by Cogniaux 1891), from which the duplicate at $\mathrm{R}$ has a fair amount of trichomes on the leaves, while the other duplicates have few if any. The remaining differences between the species are inconsistent. The absence of bracteoles was not confirmed to Löfgren or Com. Geol. Geog. S. Paulo 606 (identified as $M$. hispida by Cogniaux, in P) and Goldenberg 40 (named as M. hispida by Martins et al. 1996). All specimens have more or less thick styles, with truncate to rounded or even slightly capitate stigma. The ovary apex is papillose in every specimen, not just in $M$. trianae, as described by Cogniaux (1886-1888). The irregularly serrate margins that should be exclusive of the leaves of M. hispida also occur in Martius 943 (lectotype of $M$. trianae) and leaves with regularly dentate margins occur side by side with irregularly and deeply serrate ones in the several duplicates of Irwin 29650 (C, F, K, NY, US). The three species were described in the same work and therefore the priority principle can not be applied. The name Miconia trianae has been chosen since it honours the colombian botanist José Jerónimo Triana, who proposed the base of the current infrageneric classification of Miconia (Triana 1871), lately improved by Cogniaux (1891).

The type of Miconia brevipes var. longifolia (Warming 2189) has only fruits but, as suggested by Wurdack (1973), it undoubtedly belongs to the referred complex. Miconia brevipes does not occur in Brazil outside the Amazon basin, and it never bears unbranched trichomes, like this collection from Minas Gerais.

\section{Acknowledgements}

We thank the curators of the herbaria that either sent or allowed us to look at the specimens in their collections. We are much indebted to Karin dos Santos for the help with Regnell's collections in S. The first author receives a grant (305269/2006-2) from CNPq/ Brazil, while the second receives a doctorate grant from CAPES/Brazil.

\section{References}

Cogniaux, A. 1886-1888. Miconieae. In: Martius, C.F.P.; Eichler, A.G. \& Urban, I. (ed.). Flora brasiliensis. F. Fleisher, Munich. Vol. 14, pars 4. Pp. 64-616.

Cogniaux, A. 1891. Melastomataceae. In:De Candolle, A. \& De Candolle, C. (ed.). Monographiae Phanerogamarum. Vol. 7. G. Masson, Paris. Pp. 1-1256.

Forzza, R.C. 2009. Lista de espécies da flora do Brasil. Available in <http://florabrasil.jbrj.gov.br/2010>. Access on 21 May 2010.

Goldenberg, R. 2000. O gênero Miconia Ruiz \& Pav. (Melastomataceae). I. Listagens analíticas, II. Revisão Taxonômica da Seção Hypoxanthus (Rich. ex DC.) Hook.f. Tese de Doutorado. Universidade Estadual de Campinas, Campinas. 249p.

Goldenberg, R. 2004. O gênero Miconia no estado do Paraná, Brasil. Acta Botanica Brasilica 18: 927-947.

Goldenberg, R. \& Martin, C.V. 2008. Taxonomic notes on South-American Miconia (Melastomataceae). Harvard Papers in Botany 13: 223-227.

Goldenberg, R.; Penneys, D.S.; Almeda, F.; Judd, W.S. \& Michelangeli, F.A. 2008. Phylogeny of Miconia 
(Melastomataceae): patterns of stamen diversification in a megadiverse neotropical genus. International Journal of Plant Sciences 169: 963-979.

Hoehne, F.C. 1922. Melastomáceas dos hervários: Horto "Oswaldo Cruz", Museu Paulista, Comissão de Linhas Telegráficas Estratégicas de Mato-Grosso ao Amazonas, Jardim Botânico do Rio de Janeiro, etc. Anexos das Memórias do Instituto de Butantan, Secção de Botânica 1: 1-198.

Holmgren, P.K.; Holmgren, N.H. \& Barnett, L.C. 1990. Index herbariorum. Part I. The herbaria of the world. The New York Botanical Garden, New York. 693p.

Judd, W.S. 2007. Revision of Miconia sect. Chaenopleura (Miconieae, Melastomataceae) in the Greater Antilles. Systematic Botany Monographs 81: 1-235.

Martin, C.V.; Cremers, G. \& Goldenberg, R. 2007. Lectotypification of Miconia, Octomeris, and Staphidium (Melastomataceae) names described by Naudin. Novon 17: 362-368.
Martins A.B.; Semir, J.; Goldenberg, R. \& Martins, E. 1996. O gênero Miconia Ruiz \& Pav. (Melastomataceae) no estado de São Paulo. Acta Botanica Brasilica 10: 267-316.

Miquel, F.A.G. 1849. Melatomaceae. Linnaea 22: 537-545.

Moore, S. 1895. Phanerogamic botany. Transactions of the Linnean Society of London, ser. 2, 4: 362-363.

Triana, J. 1871. Les Melastomacées. Transactions of the Linnean Society of London 28: 1-188.

Wurdack, J.J. 1962. Melastomataceae of Santa Catarina. Sellowia 14: 109-217.

Wurdack, J.J. 1973. Melastomataceae. In: Lasser, T. (ed.). Flora de Venezuela. Vol. 8. Instituto Botánico, Caracas. Pp. 1-819.

Wurdack, J.J. 1980. Melastomataceae. In: Harling, G. \& Sparre, B. (eds.). Flora of Ecuador. Vol. 13. University of Göteborg, Göteborg. Pp. 1-404.

Wurdack, J.J.; Renner, S.S. \& Morley, T. 1993. Melastomataceae. In: Van Rijn, A.R.A.G. (ed.). Flora of the Guianas. Vol. 13. Koeltz, Königstein. Pp. 1-301.

Collectors list

Amaral, G.: 27-AX (1); Arzolla, F.: 553 (1); Balansa, B.: 1931 (3); Barreto, M.: 6715 (5); Brade, A.C.: 19124 (5); 109462 (2); Bunbury, C.J.F.: s.n. (2); Burchell, W.J.: 963 (1); 1396 (1); Campos Novaes, J.: s.n. (4); Clausen, P.: s.n. (5); 30 (3); 197 (5); 253 (1); Com. Geol. Geog. S. Paulo: 606 (5); Emmerich, M.: 1601 (1); Gardner, G. 5451 (1); Gaudichaud, C.: 777 (1); Glaziou, A.: 579 (2); 2909 (2); 3961 (1); 7627 (2); 16929 (5); 16931 (5); 17556 (2); 17562a (1); Goldenberg, R.: 40 (5); 43 (4); 62 (2); 130 (1); 596 (2); 822 (1); 28492 (3); Hahn, W.: 2135 (1); Handro, O.: 816 (2); 633 (5); Harley, R.M.: 10059 (4); Hassler, E.: 10824 (3); Hatschbach, G.G.: 30671 (1); 32455 (4); 32626 (2); 39284 (3); 44704 (5); 47215 (3); 51504 (1); 58671 (3); 62557 (4); Henschen, S.E.: s.n. (5); Herb. Mus. Vindob.: 1168 (2); 1256 (K, specimen in NY is M. sellowiana) (5); Heringer, E.P.: 17332 (4); Hoehne, F.C:: s.n. (2); 3079 (1); 28269 (2); Irwin, H.S: 29650 (5); Kirkbride, J.F.: 4347 (4); Langsdorff, G.H.: s.n. (1); 201 (3); 1311 (3); Lindberg, G.A.: 647 (3); Löfgren, A. 606 (5); Lund, P.: s.n. (1); 2285 (3); Martius, C.F.P.: s.n. (3); 943 (5); Menandro, M.S.: 72 (5); Moore, S: 173 (4); Mosen, C.W.H.: 1032 (3); Nakajima, J.A.: 1765 (4); Oliveira, A.M.: 103 (2); Oliveira, F.C.A.: 388 (4); Pereira, E. : 9191 (5); Pífano, D.S.: 404 (5); Pohl, J.B.E.: s.n. (4); 1405 (4); 1705 (4); 1178 (4); 1197 (4); 2889 (4); Pott, V.: 5670 (4); Raben, F.C.: s.n. (3); 424 (3); Regnell, A.F.: I.144 (3); II.109*-1847 (1); II.109*-19.II.1862 or 16.XII.1873 (1); II.10910.VI.1861 (1); II.109-1.XI.1864 (1); II.110-1847 (2); II.110-9.IX.1864 (2); II.110-16.X.1864 (2); II.110-16.I.1866 (2); II.110-s.d. (2); III.23 (4); III.544a (5); III.1661 (3); Reitz, R.: 5213 (2);14887 (1); Riedel, L.: s.n. (5); 4 (3); 48 (1); 416 (2); 69 (3); 565 (2); 585 (2); 1189 (1); 1411 (5); 1417 (1); 1604 (3); 1705 (5); 1762 (1); 1907 (4); 1943 (3); 2700 (4); Romero, M.: 2636 (1); Saint Hilaire, A.: B1-916 (5); B1-972 (5); Schinini, A.: 29971 (3); Schwacke, C.A.W.: s.n. (5); s.n. R 167734 (5); Sello, F.: s.n. (1); 391 (1); 1019 (2); Sellow, F.: s.n. (3); Severin, A.E.: 160 (4); Soares, M.P.: s.n. (2); Souza, V.C.: 5044 (3); Spina, A.P.: 310 (4); Strier, K.: 649 (5); Tressens, S.G.: 4681 (1); Vauthier, A.C.: 39 (5); Walter, B.: 2164 (4); Warming, E.: 2189 (5); Wasum, R.: s.n. MBM 21667 (1); 471 (1); MBM 21667 (1); Weddell, H.A.: 1064 (5); Weir, J.R.: 363 (1); Weyland, M.C.: 558 (5); Widgren, J.F.: 510 (5); 949 (1); 1144 (1); Zardini, E.M.: 2937 (1). 